\title{
Peningkatan Pemahaman Materi Keberagaman Suku Bangsa, Sosial, Dan Budaya Di Indonesia Melalui Model Think Pair Share Berbantuan Media Audio-Visual
}

\author{
Firly Nurmala ${ }^{1}$, Herinto Sidik Iriansyah ${ }^{2}$, Nanda Lega Jaya Putra ${ }^{2}$ \\ ${ }^{1} \mathrm{SD}$ Al Ihsan Jakarta Barat \\ ${ }^{2}$ STKIP Kusuma Negara \\ *mnurfirly@gmail.com
}

\begin{abstract}
Abstrak
Penelitian ini bertujuan untuk mengetahui bagaimana cara meningkatkan hasil belajar PKn di kelas IV SD Al Ihsan Jakarta Barat melalui Model Think Pair Share (TPS) berbantuan media audio-visual. Penelitian ini menggunkan studi kualitatif dengan jenis Penelitian Tindakan Kelas (PTK). Penelitian ini dilaksanakan pada semester ganjil tahun pelajaran 2019/2020 dengan dua siklus. Setiap satu siklus ada dua pertemuan. Prosedur pengumpulan data yang digunakan dalam penelitian ini adalah observasi, wawancara dan tes. Analisis data yang digunakan dalam penelitian ini adalah analisis reduksi data, deskripsi data, dan verifikasi data. Subjek pada penelitian ini adalah 23 peserta didik yang terdiri dari 12 peserta didik laki-laki dan 11 peserta didik perempuan. Hasil penelitian menunjukan bahwa pembelajaran menggunakan model pembelajaran TPS berbantuan media audio-visual dapat meningkatkan hasil belajar peserta didik. Peningkatan hasil belajar peserta didik pada siklus I rata-rata mencapai nilai 72,17, dan siklus 2 rata-rata nilai meningkat menjadi 81,09. Sehingga kesimpulan penelitian adalah: hasil belajar peserta didik pada materi keberagaman suku bangsa, sosial dan budaya di Indonesia kelas IV meningkat dengan diterapkan model pembelejaran TPS menggunakan media audio-visual.
\end{abstract}

Kata kunci: hasil belajar, media audio-visual, think pair share.

\section{PENDAHULUAN}

Seiring dengan perkembangan pendidikan di Indonesia, upaya peningkatan mutu pendidikan oleh pemerintah dan lembaga pendidikan senantiasa terus dilakukan secara menyeluruh. Pendidikan mempunyai tugas untuk menyiapkan sumber daya manusia yang berkualitas untuk perkembangan dan kemajuan untuk Indonesia. Suatu pendidikan akan dipandang sangat bermutu dan bermakna apabila pendidikan itu berhasil membentuk generasi muda yang cerdas, berkarakter, bermoral dan berkepribadian. Dengan demikian pendidikan harus dirancang agar membuat pembelajaran menyenangkan sehingga peserta didik dapat merangsang dan tertantang dalam pengembangan diri secara optimal sesuai dengan bakat dan kemampuan peserta didik. Apabila siswa belajar dengan suasana menyenangkan tentu akan berpengaruh pada hasil belajarnya.

Demikian pula halnya dengan belajar PKn, khususnya materi keberagaman suku bangsa, sosial, dan budaya di Indonesia. Pada materi ini, guru dituntut harus mampu menjelaskan pentingnya peserta didik mengenal keberagaman suku dan budaya yang ada di Indonesia dengan semua persamaan dan perbedaannya terkait dengan rasa sosial. Sehingga perbedaan yang timbul tidaklah menjadi perpecahan antara 
suku bangsa. Alasan ini lah yang diangkat pada penelitian ini sehingga memilih materi keberagaman suku bangsa, sosial, dan budaya di Indonesia.

Secara sederhana yang dimaksud dengan hasil belajar peserta didik adalah kemampuan yang diperoleh peserta didik setelah melalui kegiatan belajar di kelas. Peserta didik yang berhasil dalam belajar adalah yang berhasil mencapai tujuan pembelajaran atau tujuan intruksional (Susanto, 2013). Sedangkan menurut Ani (2004) menyatakan bahwa: hasil belajar merupakan perubahan perilaku yang diperoleh pembelajar setelah mengalami aktivitas belajar. Aspek perubahan perilaku tersebut tergantung apa yang dipelajari oleh pembelajar. Banyak hal yang mempengaruhi hasil belajar peserta didik, diantaranya: sarana prasarana, kompetensi guru, metode mengajar, dan sebagainya.

Hasil belajar merupakan kemampuan-kemampuan yang dimiliki peserta didik setelah ia menerima pengalaman belajarnya. Selain itu, hasil belajar merupakan suatu penilaian akhir dari proses dan pengenalan yang telah dilakukan berulangulang, serta akan tersimpan dalam jangka waktu lama atau bahkan tidak akan hilang selama-lamanya karena hasil belajar telah turut serta membentuk pribadi individu yang selalu ingin mencapai hasil yang lebih baik. Hasil belajar digunakan oleh guru untuk dijadikan ukuran atau kriteria dalam mencapai suatu tujuan pendidikan atau sering disebut sebagai umpan balik. Hal tersebut dapat tercapai apabila peserta didik sudah memahami belajar dengan diiringi perubahan tingkah laku yang lebih baik lagi.

Hasil belajar yang akan ditingkatkan pada PTK ini adalah terkait hasil belajar pelajaran PKn. Menurut Fajar (2005: 141), mata pelajaran kewarganegaraan merupakan mata pelajaran yang memfokuskan pada pembentukan diri yang beragam dari segi agama, sosiokultural, bahasa, usia, dan suku bangsa untuk menjadi warga Negara Indonesia yang cerdas, terampil, dan berkarakter, yang berlandaskan Pancasila dan UUD 1945. Dimana peran pelajaran PKn sangat penting bagi seluruh warga Indonesia yang mempunyai azas berdasarkan Pancasila.

Masyarakat Indonesia terdiri dari berbagai suku, Bahasa, dan budaya yang berbeda. Sekalipun masyarakat Indonesia menganut Bhinneka Tunggal Ika, selalu saja ada perselisihan karena perbedaan suku, Bahasa dan budaya. Namun karena rasa persaudaraan yang ditanamkan dari orang tua terdahulu, maka perselisihan tersebut dapat diselesaikan atau di redam. Sehingga kehidupan sosial masyarakat Indonesia tetap dalam hubungan kekeluargaan yang sangat erat.

Berdasarkan pendapat ahli yang telah dipaparkan, dapat dikatakan bahwa pembelajaran PKn adalah pembelajaran yang mengajarkan akan nilai-nilai demokrasi dan juga mengajarkan akan moral dan norma secara utuh dan berkesinambung, untuk membentuk watak warga negara yang baik, yang tahu, mau dan sadar akan hak dan kewajibannya. Karena masyarakat Indonesia terkenal dengan rasa gotong royong, kerjasamanya, dan saling berbagi, maka peneliti menawarkan solusi suatu model pembelajaran yang sesuai yaitu belajar kooperatif dengan model TPS untuk meningkatkan hasil belajar pelajaran PKn materi keberagaman suku bangsa, sosial, dan budaya di Indonesia.

TPS menurut Suyatno (2009: 54) adalah model pembelajaran kooperatif yang memiliki prosedur ditetapkan secara eksplisit memberikan waktu lebih banyak kepada peserta didik untuk memikirkan secara mendalam tentang apa yang dijelaskan atau dialami (berfikir, menjawab, dan saling membantu satu sama lain). TPS merupakan metode pembelajaran yang dapat mengaktifkan seluruh peserta 
didik selama proses pembelajaran dan memberikan kesempatan untuk bekeja sama antar peserta didik yang mempunyai kemampuan heterogen. Lebih lanjut lagi menjelaskan bahwa TPS menekankan pada struktur khusus yang dirancang untuk mempengaruhi pola-pola interaksi peserta didik. Struktur ini menghendaki agar peserta didik kerja sama, saling melengkapi dan saling bergantung dalam kelompok kecil secara kooperatif (Nurhadi, 2005).

Menurut Arends (2015) menyatakan bahwa Langkah-langkah dalam penerapan TPS yaitu: (a) berpikir (thinking), yaitu guru mengajukan suatu pertanyaan atau masalah yang dikaitkan dengan pelajaran, dan meminta peserta didik menggunakan waktu beberapa menit untuk berfikir sendiri jawaban atau masalah; (b) berpasangan (pairing), yaitu selanjutnya guru meminta peserta didik berpasangan dan mendiskusikan apa yang telah mereka peroleh, interaksi selama waktu yang disediakan dapat menyatukan jawaban jika suatu pertanyaan yang diajukan atau menyatukan gagasan apabila suatu masalah khusus yang diidentifikasi, secara normal guru memberikan waktu tidak lebih dari 4 atau 5 menit untuk berpasangan; (c) berbagi (sharing), yaitu guru meminta pasangan-pasangan untuk berbagi dengan keseluruh kelas yang telah mereka bicarakan. Hal ini efektif sampai sekitar sebagian pasangan mendapatkan kesempatan untuk melaporkan.

Menurut Handayani \& Yanti (2017), kelebihan model TPS yaitu: (a) memungkinkan peserta didik untuk merumuskan dan mengajukan pertanyaanpertanyaan mengenai materi yang diajarkan karena secara tidak langsung memperoleh contoh pertanyaan yang diajukan oleh guru, serta memperoleh kesempatan untuk memikirkan materi yang diajarkan; (b) peserta didik akan terlatih menerapkan konsep karena bertukar pendapat dan pemikiran dengan temannya untuk mendapatkan kesepakatan dalam memecahkan masalah; (c) peserta didik lebih aktif dalam pembelajaran karena menyelesaikan tugasnya dalam kelompok, dimana tiap kelompok hanya terdiri dari 2 orang; (d) peserta didik memperoleh kesempatan untuk mempresentasikan hasil diskusinya dengan seluruh peserta didik sehingga ide yang ada menyebar; (e) memungkinkan guru untuk lebih banyak memantau peserta didik dalam proses pembelajaran.

Selain memiliki kelebihan model TPS juga memiliki kelemahan. Adapun kelemahannya sebagai berikut: (a) sangat sulit diterapkan di sekolah yang rata-rata kemampuan peserta didik nya rendah dan waktu yang terbatas, (b) jumlah kelompok yang terbentuk banyak dan perlu dimonitor, (c) tidak ada penengah jika terjadi perselisihan, (d) membutuhkan waktu untuk dapat membagi kelompok.

Sanjaya (2009) menyatakan media pembelajaran adalah alat untuk memberikan perangsang bagi peserta didik supaya terjadi proses belajar. Pendapat lain (Uno, 2008) menyatakan bahwa media dalam pembelajaran adalah segala bentuk alat kamunikasi yang dapat digunakan untuk menyampaikan informasi dari sumber ke peserta didik yang bertujuan merangsang mereka untuk mengikuti kegiatan pembelajaran.

Audio-visual berasal dari kata audible dan visible. Audible mempunyai arti dapat didengar, sedangkan visible artinya dapat dilihat (Suleiman, 1985). Selanjutnya dalam kamus besar Ilmu Pengetahuan, audio adalah hal-hal yang berhubungan dengan suara atau bunyi (Save, 2006). Audio berkaitan dengan indera pendengaran, pesan yang akan disampaikan dituangkan ke dalam lambanglambang auditif, baik verbal (kedalam kata-kata atau lisan) maupun non verbal 
(Sadiman, 2006). Visual adalah hal-hal yang berkaitan dengan penglihatan; dihasilkan atau terjadi sebagai gambaran dalam ingatan (Save, 2006).

Dari teori dan beberapa konsep dan pendapat para ahli di atas dapat disintesiskan bahwa Model TPS dengan media audio-visual adalah model dan media yang dapat digunakan untuk meningkatkan hasil belajar peserta didik dalam pembelajaran PKn, karena dapat memberikan peserta didik lebih banyak kesempatan untuk berpikir dan berpendapat secara individu atau kelompok untuk merespon, membantu dan berbagi dengan bantuan media pembelajaran yang menarik membuat peserta didik lebih mudah menyerap materi yang diberikan.

Berdasarkan paparan pada pendahuluan, maka permasalahan yang akan diteliti adalah bagaimana guru dapat meningkatkan pemahaman peserta didik pada materi keberagaman suku bangsa, sosial, dan budaya di Indonesia melalui model TPS berbantuan media audio-visual di kelas IV B SDI Al-Ihsan Jakarta Barat.

\section{METODE PENELITIAN}

Metode penelitian ini merupakan penelitian tindakan kelas (PTK). Arikunto (2015) menyatakan penelitian tindakan kelas adalah suatu pencermatan terhadap kegiatan belajar berupa sebuah tindakan yang sengaja dimunculkan dan terjadi dalam sebuah kelas. PTK pada hakekatnya berupa siklus-siklus dimana siklus itu terdiri dari empat komponen utama, yaitu: (a) perencanaan, dalam tahap menyusun perencanaan ini peneliti menentukan titik fokus peristiwa yang perlu mendapatkan perhatian khusus untuk diamati, kemudian membuat RPP yang akan disajikan dalam proses pembelajaran di kelas; (b) tindakan, pada tahap ini adalah pelaksanaan yang merupakan implementasi atau penerapan kegiatan yang dilakukan oleh guru atau peneliti yang sudah dirancang, yaitu melakukan tindakan kelas; (c) pengamatan, yaitu pada tahap ini peneliti melakukan pengamatan bersama dengan pelaksanaan tindakan agar memperoleh data yang akurat untuk pebaikan pada siklus berikutnya, kemudian pada kegiatan ini yaitu mengamati, menggali dan mendemontrasikan sebagai bentuk observasi, selanjutnya dalam penelitian ini, peniliti dibantu oleh wali kelas yang bertugas sebagai observer yaitu membantu peneliti unutk mengamati peserta didik selama proses pembelajaran, selain itu observer juga mengamati dan menilai peneliti dalam menyampaikan materi pembelajaran dihadapan peserta didik; (d) refleksi, komponen ini merupakan kegiatan untuk mengemukakan kembali apa saja yang sudah dilakukan. Hasil yang diperoleh dari pengamatan dikumpulkan dan dianalisis bersama peneliti dan observer, sehingga dapat diketahui apakah kegiatan yang dilakukan mencapai tujuan yang diharapkan atau masih perlu adanya perbaikan. Tahapan ini dilakukan denagn maksud untuk memperbaiki penelitian sebelumnya.

Sumber data dalam penelitian ini terdiri dari peserta didik, guru dan teman sejawat.

1. Peserta didik

Untuk mendapatkan data tentang hasil belajar dan aktifitas peserta didik dalam proses belajar mengajar. Data hasil belajar peserta didik didapat dari pelaksanaan tes disetiap akhir siklus.

2. Guru

Semua kativitas guru pada saat mengajat digunakan untuk melihat tingkat keberhasilan implementasi pembelajaran dengan metode Penelitian Tindakan 
Kelas, hasil belajar, dan aktifitas peserta didik dalam proses belajar mengajar. Dalam penelitian ini, guru akan diamati aktivitasnya saat mengaplikasikan model TPS berbantuan media audio-visual.

3. Teman Sejawat/Kolaborator

Teman sejawat/kolaborator dimaksudkan sebagai sumber data untuk melihat implementasi PTK secara komprehensif, baik dari peserta didik maupun dari guru. Teman sejawat sebagai kolaborator dalam PTK ini adalah Ibu Riska sebagai Wali kelas IV B SDI Al-Ihsan Jakarta Barat.

Teknik pengumpulan data dalam penelitian ini dilakukan melalui:

1. Tes

Tes awal dilakukan untuk mengetahui sejauh mana penguasaan peserta didik terhadap konsep dan materi yang telah dikuasai oleh peserta didik. Tes akhir siklus dilakukan untuk menentukan tingkat ketercapaian hasil belajar peserta didik.

2. Non Tes

Jenis penilaian dengan teknik non tes sangat tepat diterapkan untuk memperoleh informasi tentang perkembangan kemampuan peserta didik secara menyeluruh. Dalam hal ini peneliti menggunakan teknik non tes diantaranya:

a. Observasi

Dilakukan untuk mengetahui kegiatan pengajaran dan aktivitas peserta didik selama penelitian sebagai upaya mengetahui kesesuaian perencanaan tindakan dengan pelaksanaan tindakan. Data diperoleh dengan pengamatan aktivitas peserta didik selama kegiatan pembelajaran.

b. Wawancara

Suatu metode penelitian yang meliputi pengumpulan data melalui interaksi verbal secara langsung antara pewawancara dengan responden agar mengetahui kondisi peserta didik.

c. Dokumentasi

Merupakan gambar-gambar digunakan sebagai data hasil pengamatan. Metode dokumentasi dalam penelitian ini berupa foto-foto, catatan lapangan peserta didik yang menggambarkan mengenai perkembangan peserta didik dalam kemampuan yaitu pada kemampuan memahami, melalui lembar kerja peserta didik, dan catatan peningkatan hasil peserta didik.

Analisis data dalam penelitian tindakan kelas ini dilakukan melalui tiga tahap, yaitu reduksi data, deskripsi data dan verifikasi data.

1. Reduksi Data

Reduksi data yaitu penyeleksian, penelitian, penyederhanaan, dan pengkategorian data yang diperoleh dari berbagai sumber dilapangan. Reduksi data memilih data penting, relevan, dan bermakna dari data yang tidak berguna, Hal ini bertujuan untuk mempermudah pengorganisasian dan keperluan analisis data serta penarikan kesimpulan.

\section{Deskripsi Data}

Deskripsi data adalah proses penampilan data secara lebih sederhana dalam bentuk paparan, naratif, referentasi grafis dan sebagainya. dalam tahap ini dilakukan dengan mengumpulkan informasi yang diperoleh dari hasil reduksi. Data yang telah disajikan dievaluasi dan disusun penafsirannya untuk menentukan tindakan selanjutnya. 


\section{Verifikasi Data}

Verifikasi data adalah proses pengambilan intisari atau kesimpulan dari sajian data yang telah terorganisasikan tersebut dalam bentuk pernyataan kalimat yang singkat dan padat tetapi mengandung pengertian luas.

\section{HASIL DAN PEMBAHASAN}

Pada siklus pertama dilaksanakan dalam 2 kali pertemuan peserta didik dibagi menjadi sebelas pasangan dengan masing-masing pasangan beranggotakan 2 peserta didik dan satu pasangan yang beranggotakan 3 peserta didik. Setiap anggota pasangan diberikan lembaran dan melakukan pembahasan dengan mengacu kepada buku pegangan dan materi tentang Keberagaman Suku Bangsa, Sosial dan Budaya di Indonesia. Hasil observasi pada siklus I dan siklus II mengalami peningkatan, demikian pula dengan hasil belajar PKn dimana nilai rata-rata yang diperoleh siswa mengalami peningkatan dari siklus I ke siklus II. Lebih lengkapnya peningkatan aktivitas peserta didik berdasarkan hasil observasi setiap siklus disajikan pada Tabel 1 berikut.

Tabel 1. Data Aktivitas peserta didik berdasarkan hasil observasi

\begin{tabular}{|c|c|c|c|}
\hline \multirow{2}{*}{ No. } & \multirow{2}{*}{ Indikator } & \multicolumn{2}{|c|}{ Ketercapaian } \\
\hline & & Siklus I & Siklus Il \\
\hline 1. & Keberanian peserta didik dalam bertanya & $78,26 \%$ & $85,21 \%$ \\
\hline 2. & $\begin{array}{l}\text { Motivasi dalam mengikuti pembelajaran } \\
\text { (menyelesaikan tugas mandiri atau tugas kelompok) }\end{array}$ & $77,17 \%$ & $85,00 \%$ \\
\hline 3. & $\begin{array}{l}\text { Interaksi peserta didik dalam mengikuti diskusi } \\
\text { kelompok }\end{array}$ & $78,91 \%$ & $83,69 \%$ \\
\hline 4. & $\begin{array}{l}\text { Hubungan peserta didik dengan guru selama kegiatan } \\
\text { pembelajaran }\end{array}$ & $79,78 \%$ & $84,56 \%$ \\
\hline 5. & Partisipasi peserta didik dalam pembelajaran & $79,13 \%$ & $86,95 \%$ \\
\hline & Rata-rata & $78,56 \%$ & $85,09 \%$ \\
\hline
\end{tabular}

Apabila digambar kan dalam bentuk diagram, agar peningkatannya lebih terlihat berdasarkan setiap indikator, ditampilkan pada Gambar 1.

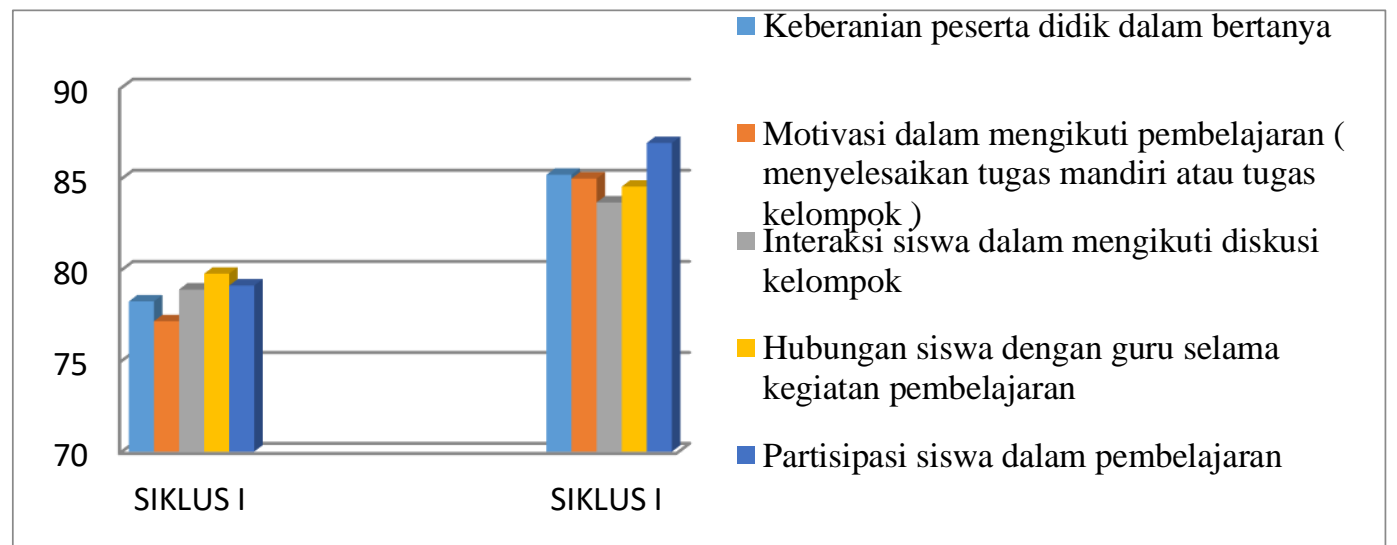

Gambar 1. Bagan Peningkatan Aktivitas Siswa Menggunakan Model TPS Berbantuan Media Audio-Visual. 
Sedangkan untuk peningkatan hasil belajar PKn disajikan pada Gambar 2 di bawah.

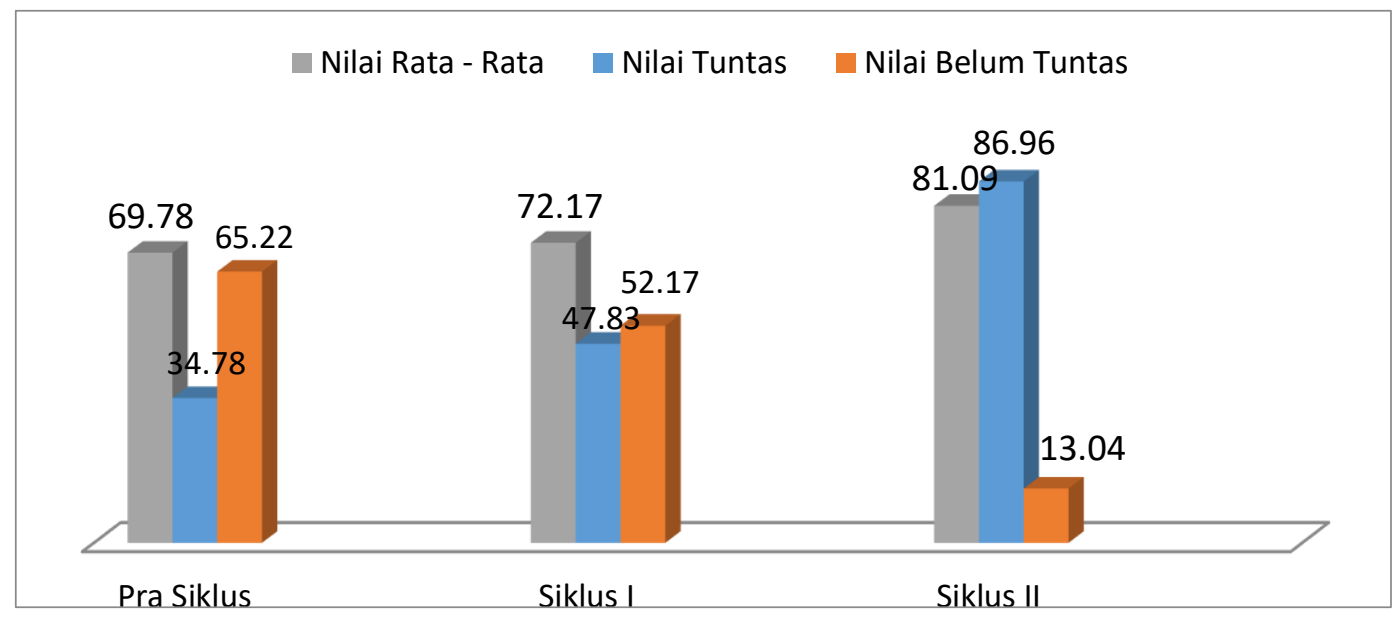

Gambar 2. Bagan hasil belajar PKn menggunakan model TPS

Berbantuan Media Audio-Visual

Mengamati data pada Tabel 1, terlihat jelas bahwa aktivitas peserta didik pada siklus I untuk indikator "hubungan peserta didik dengan guru selama kegiatan pembelajaran" tinggi. Namun pada siklus II pencapaian tertinggi pada indikator "partisipasi peserta didik dalam pembelajaran". Hal ini berarti pada saat siklus I, peserta didik masih cukup bergantung pada guru. Masih banyak yang bertanya berbagai hal kepada guru. Namun pada siklus II, sudah mulai berkurang yang bergantung kepada partisipasi guru, mereka mulai asyik belajar dengan cara diskusi dengan teman dan menggunakan media audio-visual. Keaktifan peserta didik terlihat peningkatannya.

Demikian halnya dengan indikator keberanian bertanya, semula pada siklus I masih banyak peserta didik malu dan takut bertanya pada guru (hampir 30\%), mereka baru berani saat didekati guru, dan dimulai dengan sapaan guru: Ada yang mau ditanyakan?". Tetapi pada siklus II, dengan sangat percaya diri mereka mulai berani mengangkat tangan untuk bertanya, bahkan terkadang sampai "rebutan". Ramainya saat bertanya jawab, bukanlah berarti guru tidak menguasai kelas, namun semangat belajar mereka yang luar biasa yang membuat ramai. Antusias bertanya dengan tayangan audio-visual yang disajikan guru, baik gambar maupun video-lah yang spontan mendorong mereka untuk mengacungkan tangan ingin bertanya untuk mengobati rasa ingin tahunya.

Berdasarkan kedua gambar tersebut, menunjukan aktivitas dan hasil belajar peserta didik pada pertemuan 2 siklus tergolong kategori baik, dimana secara klasikal dari keseluruhan peserta didik mencapai $\geq 80 \%$. Hal ini didukung hasil wawancara yang dilakukan dengan guru dan peserta didik mendapat jawaban yang bervariasi, dan juga mendapat jawaban yang baik karena terjadinya peningkatan hasil serta aktivitas pembelajaran yang semakin menarik.

Dari pengalaman yang diperoleh setelah melakukan penelitian guru menyadari beberapa hal yang masih kurang dan belum dilakukan. Namun setelah terlibat dalam penelitian, maka guru berusaha untuk memperbaiki dan meningkatkan keterampilannya. Perlu adanya upaya-upaya dalam pembaharuan atau inovasi yang 
mendukung kegiatan untuk perbaikan, melalui pengalaman dalam melakukan penelitian guru berupaya memahami hubungan antara gagasan dan teori dengan praktek mengajar guru serta belajar peserta didik dalam kesehariannya.

Penggunaan model TPS berbantuan media audio-visual dapat memberikan pengalaman baru terhadap model yang sudah digunakan sebelumnya. Memanfaatkan IT yang memang sedang diminati peserta didik menjadikan pembelajaran lebih menarik dan menyenangkan. Peserta didik dapat melihat dan mendengar secara nyata apa yang di contohkan atau di ceritakan guru. Mereka tidak lagi hanya membayangkan saja. Penerapan ini dapat terlihat hasil yang secara bertahap terlaksana dengan baik. Namun model yang diterapkan tergantung dengan kondisi setiap tempat dan waktu. Jadi dalam pemilihan metode banyak faktor yang harus diperhatikan, diantaranya yaitu kondisi sekolah, peserta didik dan kelas.

Berdasarkan hasil penelitian yang telah dipaparkan sebelumnya, penelitian ini cukup berhasil menunjukan pada setiap siklus adanya peningkatan, yakni peningkatan aktivitas belajar siswa dan hasil belajar mata pelajaran PKn pada materi keberagaman suku bangsa, sosial dan budaya di Indonesia melalui model TPS menggunakan media zudio visual. Peningkatan yang diperoleh cukup signifikan.

\section{KESIMPULAN}

Berdasarkan temuan dan hasil penelitian, maka disimpulkan penggunaan model TPS menggunakan media audio-visual dapat meningkatkan hasil belajar peserta didik khususnya pada pelajaran PKn materi Keberagaman Suku Bangsa, Sosial dan Budaya di Indonesia. Hal ini terbukti dengan adanya perbedaan dan peningkatan sebelum dan sesudah penerapan model TPS menggunakan media audio-visual. Penerapan model ini dapat meningkatkan keterlibatan peserta didik secara langsung dalam kegiatan pembelajaran yang pada akhirnya akan menunjang peningkatan pencapaian hasil belajar peserta didik. Hasil penelitian ini sesuai dengan penelitian Handayani dan Yanti (2017), sekalipun penelitian mereka bersifat kuantitatif, namun hasil penelitian dengan menerapkan model pembelajaran kooperatif tipe TPS dapat meningkatkan hasil belajar PKn di jenjang Sekolah Dasar.

Namun demikian, penelitian ini dapat dikembangkan lagi oleh peneliti-peneliti lain, terutama pada materi dan media yang berbeda. Karena PTK ini masih belum dapat mengamati seluruh indikator aspek aktivitas belajar dan hasil belajar. Dengan semakin banyak yang melanjutkan penelitian ini, maka sumbangsih kita sebagai peneliti akan dapat meningkatkan mutu lulusan yang siap bersaing di era 4.0 yang jelas nyata sudah dirasakan hampir seluruh aspek kehidupan menggunakan teknologi.

\section{UCAPAN TERIMA KASIH}

Penutup artikel ini, penulis mengucapkan terimakasih yang tak terhingga kepada Bapak Herinto Sidik Iriansyah, selaku ketua STKIP Kusuma Negara, dan Bapak Nanda Lega Jaya Putra selaku dosen PPKn di STKIP Kusuma Negara yang telah berkenan meluangkan waktu dan memotivasi penulis dalam menyelesaikan artikel ini, sekaligus menjadi Co-Author yang telah berbagi ilmu dan teman diskusi saat 
menyelesaikan penelitian untuk artikel ini. Semoga kebaikan Bapak-bapak menjadi ilmu yang bermanfaat dan mendapat balasan kebaikan dari Allah SWT.

\section{REFERENSI}

Ani, C. T. (2004). Psikologi Belajar. Semarang: UNNES Press.

Arends, R. I. (2015). Learning to Teach. New York: McGraw-Hill Education.

Arikunto, S., Suhardjono, \& Supardi. (2015). Penelitian Tindakan Kelas. Jakarta: Bumi Aksara.

Fajar, A. (2005). Portopolio dalam Pelajaran IPS. Bandung: Remaja Rosda Karya. Handayani, R. D., \& Yanti, Y. (2017). Pengaruh Model Pembelajaran Kooperatif Tipe Think Pair Share terhadap Hasil Belajar PKn Siswa di Kelas IV MI Terpadu Muhammadiyah Sukarame Bandar Lampung. Terampil: Jurnal Pendidikan dan Pembelajaran Dasar, 4(2), 107-123.

Nurhadi. (2005). Kurikulm 2005 (Pertanyaan dan Jawaban). Jakarta: Grasindo.

Sadiman, A. S. (2006). Media Pendidikan Pengertian, Pengembangan dan Pemanfaatannya. Jakarta: Raja Grafindo Persada.

Sanjaya, W. (2009). Perencanaan dan Desain Sistem Pembelajaran. Jakarta: Kencana.

Save, M. D. (2006). Kamus Besar Ilmu Pengetahuan. Jakarta: Lembaga Kajian Kebudayaan Nusantara.

Suleiman, A. H. (1985). Media audio-visual untuk pengajaran, penerangan dan penyuluhan. Jakarta: Gramedia.

Susanto, A. (2013). Teori Belajar dan Pembelajaran di Sekolah Dasar. Jakarta: Kencana prenada media.

Suyatno. (2009). Menjelajah Pembelajaran Inofatif. Sidoarjo: Masmedia Buana Pusaka.

Uno, H. B. (2008). Profesi Kependidikan: Problema, Solusi, dan Reformasi Pendidikan di Indonesia. Jakarta: Bumi Aksara. 